\title{
モアレパターンに現れる構造歪みが誘起する 窒化鉄原子層のナノ変調電子状態
}

\author{
家永紘一郎*・小森文夫 \\ 東京大学物性研究所 恶 277-8581 柏市柏の葉 5-1-5 \\ (2018 年 7 月 20 日受付；2018 年 8 月 20 日掲載決定)
}

\section{Nano-modulated Electronic States Induced by Structural Strain in a Moiré Pattern on an Iron-nitride Atomic Layer}

\author{
Koichiro IenagA* and Fumio Komori \\ Institute for Solid State Physics, The University of Tokyo, Kashiwanoha, Kashiwa-shi, Chiba 277-8581
}

(Received July 20, 2018 ; Accepted August 20, 2018)

\begin{abstract}
Strain-induced modulation of electronic states in a Moiré pattern on a hexagonal-type FeN monoatomic layer has been studied using scanning tunneling microscopy and spectroscopy. The hexagonal FeN film is stabilized by a strong $\mathrm{Fe}-\mathrm{N}$ bond even on the square $\mathrm{Cu}(001)$ substrate and shows a strip structure comprising regular and deformed hexagonal lattices. By analyzing the atomically resolved images, we have found that the lattice is periodically deformed along a hypothetical Moiré pattern between a perfect hexagonal lattice and the square $\mathrm{Cu}(001)$ lattice. Moreover, $\mathrm{d} I / \mathrm{d} V$ spectra exhibit spatial change of the unoccupied local density of states, which is attributed to an energy shift of the antibonding states due to the periodic compressive lattice strain.
\end{abstract}

KEYWORDS : Moiré pattern, crystal symmetry, surface strain, electronic structure, iron-nitride

\section{1. は じめに}

基板の格子定数を引き継いで成長したエピタキシャル 薄膜は，基板との強い結合によって格子が圧縮または伸 張され，バルク状態と大きく異なる物性を示す場合があ る。この面内の圧力効果によって, 例えばシリコン基板 上のシリコン-ゲルマニウム薄膜などの半導体ではバン ドギャップが増大し ${ }^{1 \sim 3)}$, 鉄 $(\mathrm{Fe})$ やコバルトなどの磁 性薄膜では磁気秩序構造の変化や磁化容易軸の回転が生 じ4 6), 非磁性 $4 d$ 金属のルテニウムでは強磁性の発現が 報告されている7)。

上記の均一な物性変化とは対照的に, 薄膜が自身の格 子定数を維持したまま成長した場合，基板とのミスマッ チによりナノスケールのモアレパターンが生じる ${ }^{8 \sim 17)}$

* 現在, 東京工業大学理学院

E-mail : ienaga.k.aa@m.titech.ac.jp
このとき界面では，基板への積層サイトがホローからオ ントップへと周期的に変化しており，薄膜は面直方向の 構造緩和や電子状態の空間変化を示すことになる。この ような周期的変調効果は, モアレがナノドットの自己組 織化のテンプレートとして働くことにも現れてい $ろ^{8 \sim 10)}$ 。また, 本特集号のモアレ誘起超伝導のように, モアレによる周期ポテンシャルが原子層全体の電子状態 を激的に変化させる場合もある ${ }^{11,12)}$ 。以下，本稿では特 に，モアレに付随した構造緩和が電子状態を空間的に変 調させる効果に焦点を当てる。

電子状態の空間変化は, 面直方向のうねりを伴う単原

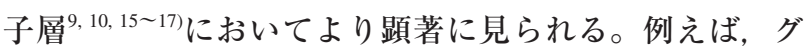
ラフェンを種々の遷移金属基板上に作製した研究では, グラフェンの $\pi$ 軌道と基板の $d$ 軌道の結合が強いほど 大きく波打つことが報告され ${ }^{15)}$, 電荷移動や仕事関数な どの空間変化も比較的大きく観測されている ${ }^{16,17)}$ 。この ように基板との結合の強さは電子状態の変調度合いを決 
める重要なパラメータであるものの, 基板との結合が強 すぎると, 基板の格子定数に沿って薄膜成長するためモ アレは消失するはずである。つまり，原子層面内の結合 と基板との結合がちょうどバランスするような状況にお いて, 最も強い空間変調効果が期待できる。

そこで我々は窒化鉄（ $\mathrm{Fe} \mathrm{x})$ の単原子層に着目した。 $\mathrm{Fe}_{\mathrm{x}} \mathrm{N}$ では窒素（N）原子と $\mathrm{Fe}$ 原子の共有結合によって 強いネットワークが形成されている ${ }^{18-20)}$ 。このため, 正 方格子である銅 $(\mathrm{Cu})$ の $(001)$ 基板上でも三角格子構造 を持つ $\mathrm{FeN}$ (hex-FeN) の原子層が安定に形成され，モ アレが生じることが判明した211。このような基板とは異 なる対称性をもつ積層は $\mathrm{Cu}_{2} \mathrm{~N}$ (正方格子) $/ \mathrm{Cu}(111)$ （三 角格子 ${ }^{22,23)}$ のように他の窒化物原子層でも観測されて おり, 最近 $\mathrm{Fe}_{2} \mathrm{~N}$ (正方格子) $/ \mathrm{Cu}(111)$ (三角格子) ${ }^{24)}$ でも 観測された。さらに, 窒化物原子層と $\mathrm{Cu}$ 基板との間に は, $\mathrm{N}$ 原子の $p$ 軌道と $\mathrm{Cu} の d$ 軌道を介して強い結合が 生じる ${ }^{25)}$ 。この結果, モアレに沿って周期的に大きな面 内格子歪が生じ, 電子状態が強く変調されることが詳細 な STM 観測によって明らかになった。

今回確認された $\mathrm{Cu}(001)$ 上の hex-FeN 単原子層は, 正 三角形格子と圧縮されて歪んだ三角格子のストライプ構 造を形成する。本稿ではまず単原子層の構造と, 基板と の積層関係を詳細に調べた結果を説明する。その後, こ のストライプ構造が三角格子を $\mathrm{Cu}(001)$ 上に重ねた場合 のモアレパターンに由来することを示す。最後に, 走査 トンネル分光（STS）を用いて周期的な歪み構造と局所 電子状態密度（LDOS）の関係を調べた結果について述 ベる ${ }^{21)}$

\section{2. 実験手法・試料}

\section{1 窒化鉄}

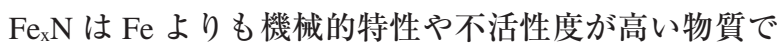
あり, $\mathrm{N}$ 原子の含有率によって多彩な構造と物性を示 $す^{18,26)}$ 。特に磁気的特性に優れた $\left.\alpha^{\prime \prime}-\mathrm{Fe}_{16} \mathrm{~N}_{2}{ }^{27}, 28\right)$ や $\gamma^{\prime}$ $\mathrm{Fe}_{4} \mathrm{~N}^{29 \sim 35}$ は元素戦略の観点からも広く研究されている。 薄膜試料としては $\gamma^{\prime}-\mathrm{Fe}_{4} \mathrm{~N}(001) / \mathrm{Cu}(001)$ のエピタキシャ 儿膜が知られており, $\gamma^{\prime}-\mathrm{Fe}_{4} \mathrm{~N}$ の構成要素である $\mathrm{Fe}_{2} \mathrm{~N}$ 面 の単原子層成長も確認されている ${ }^{30 \sim 34)}$ 。Fig. 1 に示すよ うに, $\mathrm{Cu}(001)$ 基板の原子間距離 $2.56 \AA$ は $\mathrm{Fe}_{2} \mathrm{~N}$ 面の $\mathrm{Fe}$ 間距離 $2.68 \AA$ と非常に近いが, 閃亜鉛鉱型 $(\mathrm{ZnS}$ 型) の構造を持つ $\gamma^{\prime \prime}-\mathrm{FeN}^{36 \sim 38}$ の (111) 面の原子列間距離 2.65 ^とも近い。次の試料作製の節に示すように, $\mathrm{N}$ 原子の 供給条件によって $\mathrm{Fe}_{2} \mathrm{~N}$ だけでなく hex-FeN 単原子層も 成長することがわかった。

\section{2 試料作製}

試料作製には $\mathrm{Cu}(001)$ 基板を用い, アルゴンイオンス
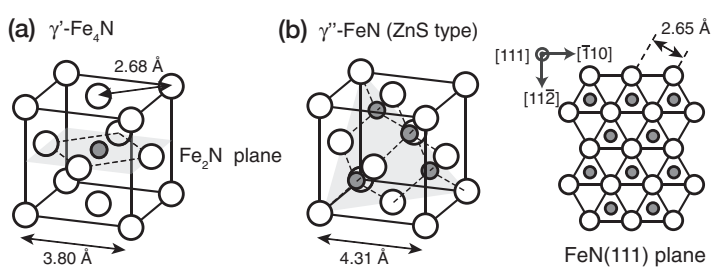

Fig. 1. (a) $\gamma^{\prime}-\mathrm{Fe}_{4} \mathrm{~N}$ (fcc). (b) $\gamma^{\prime \prime}-\mathrm{FeN}(\mathrm{ZnS}$ structure) and its (111) plane. In all schematics, white and gray circles correspond to $\mathrm{Fe}$ and $\mathrm{N}$ atoms, respectively.

パッタリングと $820 \mathrm{~K}$ でのアニーリングを繰り返すこと で基板表面の清浄化を行った。その後, 室温下で 0.5 $\mathrm{keV}$ での $\mathrm{N}^{+}$イオンの打ち込みと $\mathrm{Fe}$ の蒸着を行い, 570 $\mathrm{K}$ で 15 分程アニーリングを行った。このとき, $\mathrm{N}^{+}$イオ ンの供給が不十分であると, $\mathrm{Cu}(001)$ の対称性と整合し た $\mathrm{Fe}_{2} \mathrm{~N}$ 単原子層のみが形成される。 $\mathrm{N}^{+}$イオンを過剩に 供給した場合にのみ, hex-FeN 単原子層を作製すること ができた。

\section{3 走查トンネル顕微/分光法}

STM では，金属探針と試料の間に真空障壁を介して バイアス電圧 $\left(V_{\mathrm{b}}\right)$ を印加し, 流れるトンネル電流 $\left(I_{\mathrm{t}}\right)$ によって表面構造や LODS を原子スケールの分解能で 測定することが出来る。実空間像は $V_{\mathrm{b}}$ と $I_{\mathrm{t}}$ を一定に保 ちながら探針高さをスキャンすることで取得した。探針 高さを固定し， $V_{\mathrm{b}}$ をスイープして $\mathrm{d} \mathrm{I}_{\mathrm{t}} / \mathrm{d} V_{\mathrm{b}}$ スペクトルを 測定することを特にSTS と呼び, LDOS を調べることが 出来る。 $\mathrm{d} \mathrm{I}_{\mathrm{t}} / \mathrm{d} V_{\mathrm{b}}$ スペクトルは $20 \mathrm{mV}_{\mathrm{p}-\mathrm{p}}, 719 \mathrm{~Hz}$ の交流 電圧を重畳させてロックインアンプを用いて測定した。 探針には夕ングステンを使用し， $77 \mathrm{~K}$ で測定を行った。 STM チャンバーには表面試料作製用のチャンバーが連 結しており, 試料作製後に表面を大気中に暴露すること なくSTM 観測を行うことが可能である。

\section{3. 実験結果・考察}

\section{1 hex-FeN 単原子層のストライプ構造}

Fig. 2 は作製した試料の STM 像である。Fig. 2 (a) のように，テラス上にはストライプ構造を示している hex- $\mathrm{FeN}$ 層と, 正方格子状の $\mathrm{Fe}_{2} \mathrm{~N}$ 層, 裸の $\mathrm{Cu}(001)$ 面が 共存している。像のコントラストはLDOS の違いに起 因し, hex-FeN は $E_{\mathrm{F}}$ から $0.5 \mathrm{eV}$ までのエネルギー範囲 で, 最も低い LDOS を示す。Fig. 2 (b) はストライプ領 域の拡大図である。白い実線は Fig. 3 (a) の原子分解 像からわかる原子位置を示しており, 格子 $\mathrm{A}$ と記した 暗い領域では原子間距離 $3.10 \AA$ の正三角形格子が観測 され, 格子 B と書かれた明るい領域内では歪んだ三角 格子が観測された。Fig. 3（a）からわかるように, 最も 
明るい点をつないだ黒い破線の三角格子は，歪んだ三角 格子を作る原子の $1 / 3$ が周期的に高くなるバックリング 構造に起因する。白い破線はバックリング構造のドメイ ン境界であり，3，4 周期ごとに不規則に現れている。
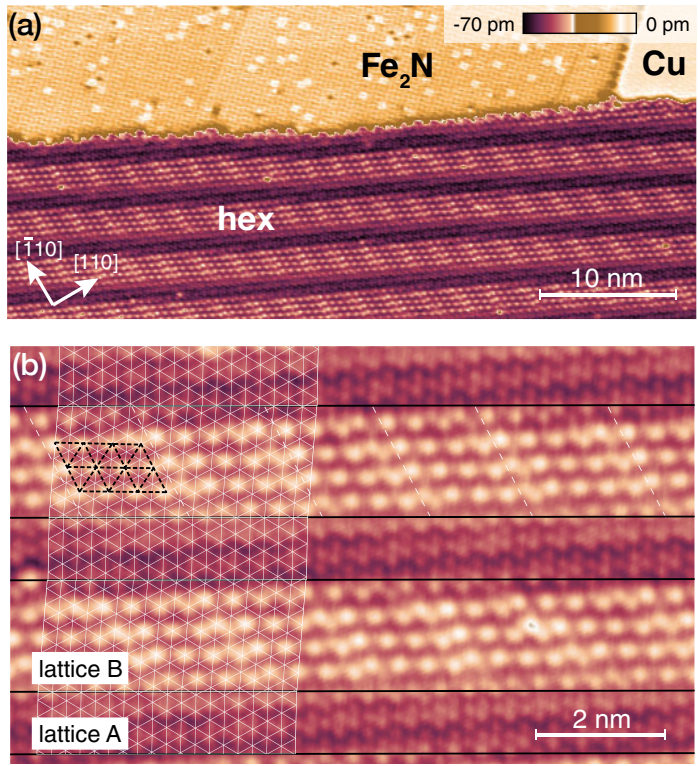

Fig. 2. (color online). Topographic images of iron nitride monoatomic layers on $\mathrm{Cu}(001) .{ }^{21)}$ (a) The hex-FeN, $\mathrm{Fe}_{2} \mathrm{~N}$ and bare $\mathrm{Cu}(001)$ surface within a single terrace obtained at $I_{\mathrm{t}}=500$ $\mathrm{pA}, V_{\mathrm{b}}=-0.1 \mathrm{~V}$. (b) Magnified image of a striped hexagonal region at $I_{\mathrm{t}}=0.5 \mathrm{nA}, V_{\mathrm{b}}=-0.1 \mathrm{~V}$. Solid black lines along the stripe direction divide the stripe structure into lattice A and B, which are depicted by the white lattices. The lattice B contains a buckled structure as marked by dashed black lines. The dashed white lines indicate phase boundaries of the buckled structure.
Fig. 3 （a）はストライプ領域を原子分解能で観測した STM 像であり，観測された三角格子を抜き出したもの が Fig. 3（b）中の黒い害線である。Fig. 3（c）にその単 位格子を示す。 $[0,1]$ 方向の格子線は格子 A と B で共有 され，線間は常に等間隔に保たれているが，格子 B の $[0,1]$ ベクトルの長さは格子 $\mathrm{A}$ のもより $3.5 \%$ 短い。し たがって, 格子 B の面積は $3.5 \%$ の圧縮を受けており, $\mathrm{Fe}$ 原子同士はより接近していることがわかる。また, この圧縮により高さ $10 \mathrm{pm}$ 程度のバックリングが生じ たと解釈できる。さらに Fig. 3 （b）において一番左の 格子 A を延長した黒い破線に注目すると, 格子 A の [1,0]方向の格子線は，格子 B を挟んで隣合う格子 A の ものとちょうど半位相ズレていることがわかる。

\section{$3.2 \mathrm{Cu}(001)$ 基板への積層}

Fig. 3 (a) の左端には，ダイマー状の再構成 30 年を示 す $\mathrm{Fe}_{2} \mathrm{~N}$ が hex-FeN と同一面内に形成されている。 $\mathrm{Fe}_{2} \mathrm{~N}$ と $\mathrm{Cu}(001)$ の積層関係は先行研究により既知であるた め, Fig. 3（a）の黒い破線のように下地の原子位置を描 くことができ, hex-FeN ストライプの積層構造が明確に わかる。この結果, hex-FeN ストライプの全ての原子が $\mathrm{Cu}$ のオントップサイトを避けて積層していることがわ かった。次に議論するように，格子 A の正三角格子 （原子間距離 $3.10 \AA ̊ \AA)$ ）だけを $\mathrm{Cu}(001)$ 格子全面に重ねた 場合では，オントップとホローの両サイトへの積層が周 期的に生じる。したがって，ストライプ構造の形成によ り格子 B 領域で生じる面内歪みのエネルギーを損した としても，オントップサイトへの積層を避けた方がトー タルの格子エネルギーが低くなると解釈できる。
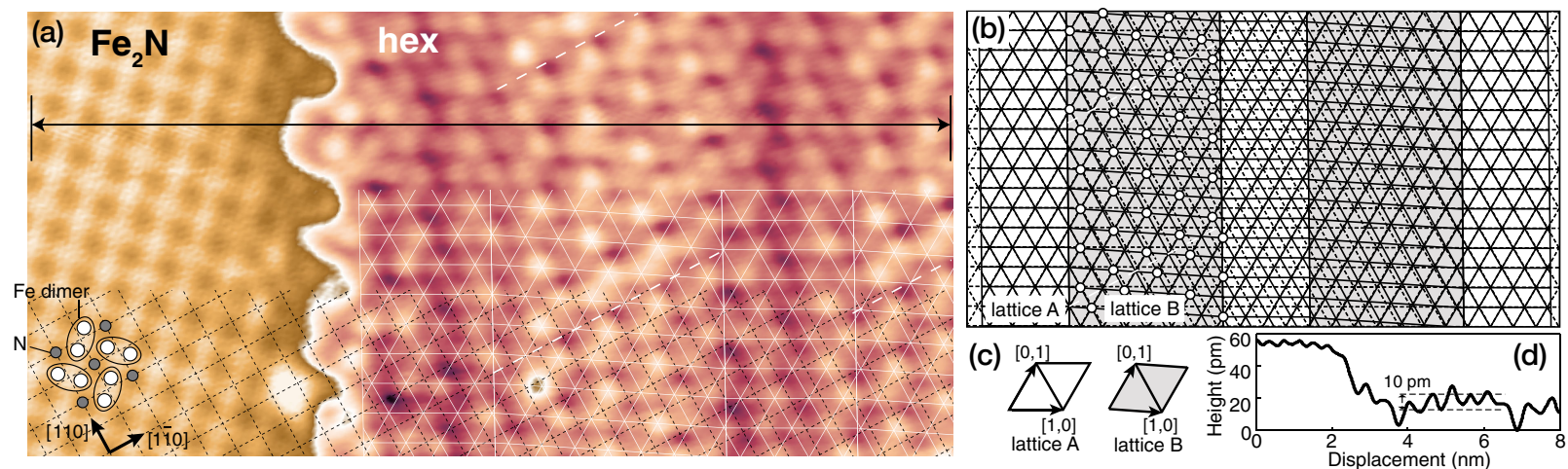

Fig. 3. (color online). (a) Atomic image of a hex-FeN film and $\mathrm{Fe}_{2} \mathrm{~N}$ at $I_{\mathrm{t}}=3.0 \mathrm{nA}, V_{\mathrm{b}}=0.2 \mathrm{~V}$. Dashed black and solid white lines correspond to lattices of underlying $\mathrm{Cu}(001)$ and hexagonal region consisting of regular (lattice $\mathrm{A}$ ) and strained region (lattice B), respectively. Dashed white lines represent phase boundaries of the buckled structure. Atomic configuration of $\mathrm{Fe}_{2} \mathrm{~N}$ is illustrated with a schematic model in the bottom-left of the panel, where white balls represent iron atoms, and gray nitrogen. (b) Extracted hexagonal lattices from (a) are drawn by solid black lattices. Dashed black lattice extrapolated from the lattice A is superimposed for comparison. The buckled atoms in the lattice B are represented with white circles. Dashed white lines indicate phase boundaries of the buckled structure. (c) Unit lattice vectors $[1,0]$, $[0,1]$ of the lattices A and B. (d) An averaged height profile along a solid black line in (a). 
(a)

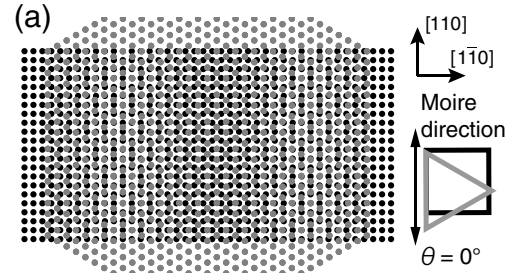

(b)

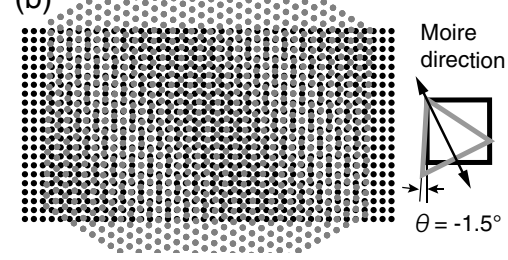

(c)

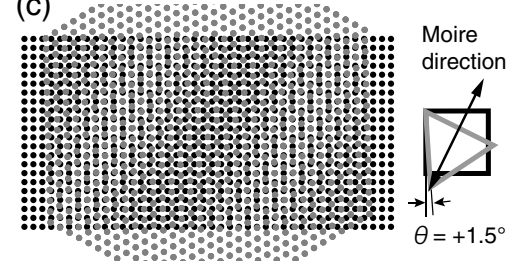

(d)

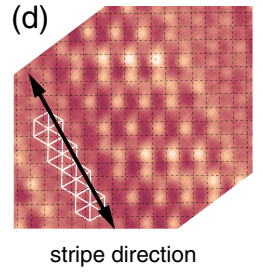

(e)

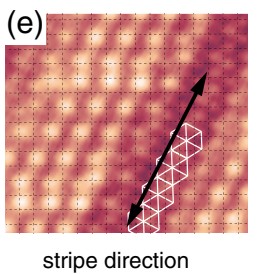

Fig. 4. (color online). (a)-(c) Moire patterns formed between a perfect (free-standing) hexagonal lattice with the interatomic distance of $3.10 \AA$ and the $\mathrm{Cu}(001)$ lattice with the interatomic distance of $2.56 \AA$. Rotation angle of the hexagonal lattice to $\mathrm{Cu}(001)$ is $0^{\circ},-1.5^{\circ}$ and $1.5^{\circ}$ in (a)-(c), respectively. (d)(e) STM images of striped hexagonal films at $I_{\mathrm{t}}=1.0 \mathrm{nA}$, $V_{\mathrm{b}}=-0.1 \mathrm{~V}$. Two orientations of the stripe for lattice A (marked with white triangles) are confirmed. The dashed black lattices indicate underlying $\mathrm{Cu}(001)$ estimated from the stacking relation in Fig. 3(b).

\section{3 ストライプ構造とモアレの関係}

それでは，なぜストライプ状に歪む必要があるのであ ろうか。ここではまず, 歪みの無い正三角格子である格 子 $\mathrm{A}$ だけで構成された原子層を考える。 $\mathrm{Cu}(001)$ 基板上 にこの正三角格子を重ねた場合，2つの格子の回転角 $\theta$ に応じたモアレパターンが生じる。Fig. 4 (a) のように 三角形の 1 辺が正方形の 1 辺と完全に平行である場合 $\left(\theta=0^{\circ}\right), \mathrm{Cu}$ の原子間距離 $2.56 \AA$ と三角格子の原子列 間距離 $2.68 \AA(=3.10 \AA \times \sqrt{3} / 2)$ のわずかな差により ストライプ状のモアレ構造が生じる。このときのモアレ 方向は揃えた辺の方向と同じである。Fig. 4（b） (c) の ように三角格子が $\theta= \pm 1.5^{\circ}$ 傾いたとき, モアレ方向は 約 $\mp 30^{\circ}$ 回転し, 三角格子の次隣接サイト方向にほほ平 行になる。実は Fig. 3（a）で観測された原子像では, 格子 A の正三角格子の 1 辺は $\mathrm{Cu}(001)$ の [110]方向に対 して約 $+1.5^{\circ}$ 傾いており，ストライプの向きも約 $-30^{\circ}$ 傾いている。したがってこのストライプ構造は, $\mathrm{Cu}(001)$ に格子 A の正三角格子を重ねた場合のモアレ構 造に起因することが強く示唆される。さらに Fig. 4 (d) （e）に示すように, 実験では約 $\pm 30^{\circ}$ 傾いている 2 種類
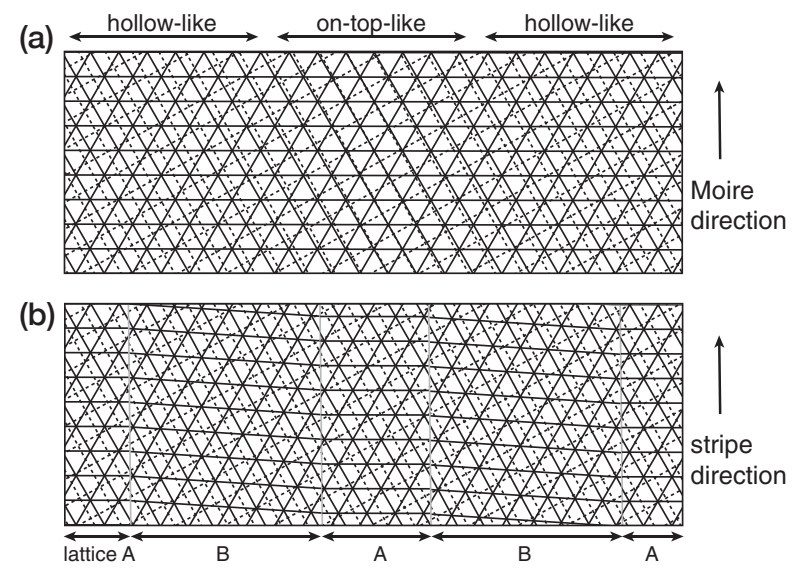

Fig. 5. (a) An enlarged image of Fig. 4(c). (b) Extracted stacking relation of the observed stripe structure on $\mathrm{Cu}(001)$ in Fig. 3(a).

のストライプだけが観測されており，この積層関係が最 も安定であることがわかる。

次に, このモアレモデルと実際に観測された構造を比 較してみる。Fig. 4 (c) の $\theta=+1.5^{\circ}$ のモデルを拡大し たものがFig. 5 (a) である。図の両端側では実線の正 三角格子が破線の正方格子のホローサイトもしくはブリ ッジサイトを占有しており, 図の中央ではブリッジサイ トもしくはオントップサイトを占有している。これに対 して，実際に観測された Fig. 3 （b）の格子を $\theta=+1.5^{\circ}$ の回転角で $\mathrm{Cu}(001)$ に重ねたものが Fig. 5 （b）である。 格子 B を挟んで隣合う 2 つ格子 A において, [1,0]方 向の格子線が半位相ズレているため, オントップサイト がみごとに避けられていることがわかる。格子 B の歪 みは 2 つ格子 A をスムーズに結ぶように生じている。 また，ストライプ方向がモアレ方向と一致しているとい う事実は, Fig. 5（b）の積層関係がストライプ方向に沿 ってどこまでも続くことを保障している。以上のよう に, 観測されたストライプ状の歪み構造は, 単なる正三 角格子の積層と比べて積層エネルギーが低いと解釈でき る。このようなモアレを引きずった変形は, 面内の結合 と基板との結合が絶妙にバランスしているために生じた と考えられる。

\section{4 周期的格子歪みによる電子状態の変調}

Fig. 6 （a）は Fig. 6（b）の STM 像の黒い破線に沿っ て $\mathrm{Fe}_{2} \mathrm{~N}$ から hex-FeN にかけて取得した $\mathrm{d} I / \mathrm{d} V$ スペクト ルであり, Fig. 6 (c) は各シンボルで示した位置のスペ クトルを抜粋したものである。全てのスペクトルは 3.0 〜 $4.0 \mathrm{~V}$ の範囲にピークもしくはハンプを示している。 特に hex-FeN 上では, ストライプ周期に沿ってピーク位 置が $0.6 \mathrm{~V}$ という非常に大きな振幅で振動していること がわかる。このスペクトルの空間変化は格子 A から B 


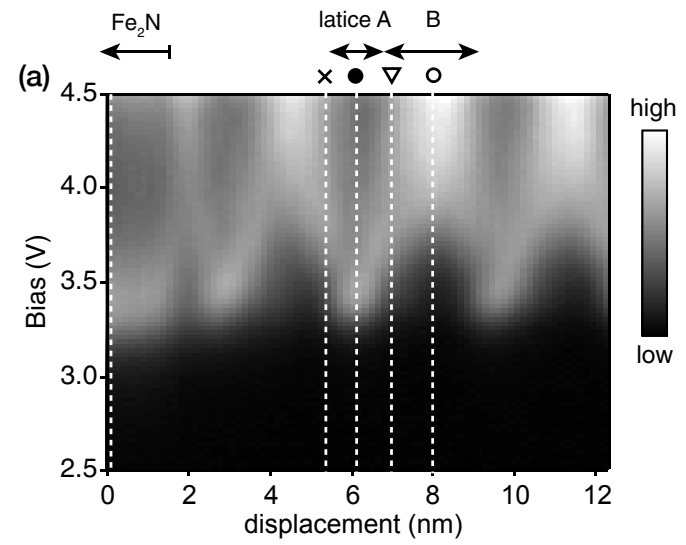

(b)

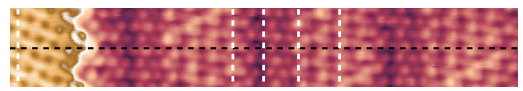

(c)

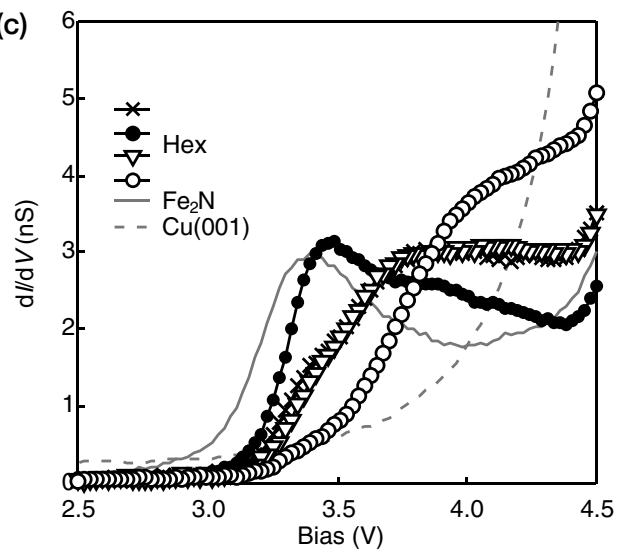

Fig. 6. (color online). Effect of periodic strain to the electronic states. (a) $\mathrm{d} I / \mathrm{d} V$ spectra measured along the dashed black line shown in (b) from $\mathrm{Fe}_{2} \mathrm{~N}$ (left) to the striped hexagonal film (right). Gray scale corresponds to the amplitude of $\mathrm{d} I / \mathrm{d} V$. Current and bias set points are $I_{\mathrm{t}}=3.0 \mathrm{nA}$ and $V_{\mathrm{b}}=4.5 \mathrm{~V}$. (b) STM image near a boundary between $\mathrm{Fe}_{2} \mathrm{~N}$ and a striped hexagonal film. (c) Representative spectra obtained on hexagonal film and $\mathrm{Fe}_{2} \mathrm{~N}$ extracted from (a). The plotted symbols of spectra correspond to those indicating the position in (a) with the vertical dashed line. A comparable spectrum of $\mathrm{Cu}(001)$ is also presented with dashed gray line.

にかけてなだらかに生じている。

このピークの起源について, 先行研究の結果を基に考 察する。 $\mathrm{Fe}_{2} \mathrm{~N}$ 層を構成要素として含む $\gamma^{\prime}-\mathrm{Fe}_{4} \mathrm{~N}$ の理論計 算では, $3.5 \mathrm{~V}(-7.0 \mathrm{~V})$ 付近に $\mathrm{N} 2 p-\mathrm{Fe} 3 d$ 反結合性 (結合性）軌道に基づくLDOS が示されている ${ }^{39}$ 。ここの ような反結合性軌道に由来した非占有状態は $\mathrm{Cu}_{2} \mathrm{~N}$ 単原 子層でも確認されていることから ${ }^{40,41)}$, 窒化物で広く見 られるものと予想される。このため, $\mathrm{Fe}_{2} \mathrm{~N}$ と hex- $\mathrm{FeN}$ で観測された $3.5 \mathrm{~V}$ 付近のピークも $\mathrm{N} 2 p-\mathrm{Fe} 3 d$ 反結合 性軌道に基づくものと考えられる。

最後に，ピーク位置の振動の起源を考察する。ストラ イプ周期とピーク位置の振動周期の一致は，ストライプ
内で生じている周期的な格子歪みが電子状態を変化させ ていることを意味する。一般に格子が圧縮された場合, 軌道の重なりは増加し, 金属であればバンド幅が, 半導 体であればバンドギャップが広がる。したがって，今回 観測された $0.6 \mathrm{~V}$ という非常に大きな LDOS のピーク位 置の変化は，格子 $\mathrm{B}$ 内の圧縮歪みが反結合性軌道を高 エネルギー側にシフトさせたためと解釈できる。なお, 結合性軌道のピークは今回の測定のレンジ外である $-7.0 \mathrm{~V}$ に存在すると予想される ${ }^{399}$ 。

\section{4. まと め}

本研究では, hex-FeN/Cu(001) という対称性が異なる 積層を示す原子層に対して，STM を用いて原子スケー ルの構造と LDOS を調べた。hex-FeN は Fe-N 間の強い 結合により $\mathrm{Cu}(001)$ 上でも安定化され，正三角格子と圧 縮歪みを受けた三角格子からなるストライプ構造を示し た。このストライプ状の歪みは，三角格子と $\mathrm{Cu}(001) に$ よるモアレ構造の積層エネルギーを下げるために生じて いることが分かった。このようなモアレを引きずった変 形は，面内と基板間の結合がバランスしているために生 じたと考えられる。さらにSTS 測定から，ストライプ 状の圧縮歪みが LDOS を空間的に大きく変調させてい ることがわかった。

hex-FeN 原子層の母物質であるバルク $\gamma^{\prime \prime}-\mathrm{FeN}$ は非磁 性金属であるが，この単原子層における磁性はあらため て調べるべきである。そのためには理論計算や, $\mathrm{Fe}_{2} \mathrm{~N}$ 層を排除した hex-FeN だけの試料を作製した後，X 線磁 気円二色性分光（XMCD）などの実験を行う必要があ る。今回はSTS によるLDOS の評価のみ行ったが, 磁 性や輸送特性なども同様に周期的な歪みによって変調さ れているかもしれない。

また今回の結果は，他の単原子層に抒いても面内と界 面の結合が同程度になるよう適切な基板を選ぶことで, 周期的な歪み構造による強い物性変調効果が生じること を示唆している。最近，服部らによって，強磁性体の $\mathrm{Fe}_{2} \mathrm{~N}$ 単原子膜が $\mathrm{Cu}(111)$ にモアレを伴って成長すること が報告されている ${ }^{24)} \mathrm{Fe}_{2} \mathrm{~N}$ は 4 回対称の面内異方性を持 つため ${ }^{32,34,35)}$, 磁気構造がどのように変化しているか興 味が持たれる。このような方針で物質開発を行うこと で, バルク物質にはない新奇な磁気構造, 輸送特性, 強 相関電子現象などを示す表面試料を作製できるのではな いかと期待している。

\section{謝 辞}

本研究は, 宮町俊生氏, 高橋文雄氏, 河村紀一氏との 共同研究によるもので，多くのご助言，ご協力をいただ 
きました。また山田正理氏, 金聖憲氏にも多く議論して いただきました。この場を扔借りして梁く感謝申し上げ ます。また本研究の一部は, 科学研究費・基盤研究 （B）(No. 26287061, 代表 : 小森文夫), 若手研究 (A) (No. 16H05963)，放送文化基金助成金，島津科学技術振 興財団助成金, 池谷科学技術振興財団助成金 (上記 4 万 の代表: 宮町俊生), 特別研究員奨励費（No. 15J10476）,

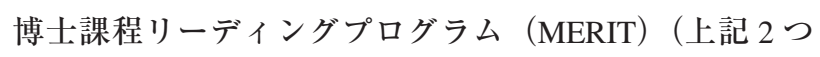
の代表 : 高橋文雄) の助成を受けて行われました。

\section{文献}

1) G.H. Olsen, C.J. Nuese and R.T. Smith : J. Appl. Phys. 49, 5523 (1978).

2) T.P. Pearsall, F.H. Pollak, J.C. Bean and R. Hull : Phys. Rev. B 33, 6821 (1986).

3) C.G. Van de Walle and R.M. Martin : Phys. Rev. B 34, 5621 (1986).

4) P.F. Carcia, A.D. Meinhaldt and A. Suna : Appl. Phys. Lett. 47, 178 (1985).

5) P. Krams, F. Lauks, R.L. Stamps, B. Hillebrands and G. Güntherodt : Phys. Rev. Lett. 69, 3674 (1992).

6) J. Giergiel, J. Shen, J. Woltersdorf, A. Kirilyuk and J. Kirschner : Phys. Rev. B 52, 8528 (1995).

7) R. Pfandzelter, G. Steierl and C. Rau : Phys. Rev. Lett. 74, 3467 (1995).

8) H.Y. Lin, Y.P. Chiu, L.W. Huang, Y.W. Chen, T.Y. Fu, C.S. Chang and T.T. Tsong : Phys. Rev. Lett. 94, 136101 (2005).

9) A.T. N'Diaye, S. Bleikamp, P.J. Feibelman and T. Michely : Phys. Rev. Lett. 97, 215501 (2006).

10) H. Cun, M. Iannuzzi, A. Hemmi, S. Roth, J. Osterwalder and T. Greber : Nano Lett. 13, 2098 (2013).

11) M. Yankowitz, J. Xue, D. Cormode, J.D. SanchezYamagishi, K. Watanabe, T. Taniguchi, P. JarilloHerrero, P. Jacquod and B.J. LeRoy : Nat. Phys. 8, 382 (2012).

12) Y. Cao, V. Fatemi, S. Fang, K. Watanabe, T. Taniguchi, E. Kaxiras and P. Jarillo-Herrero : Nature 556, 43 (2018).

13) W.B. Jian, W.B. Su, C.S. Chang and T.T. Tsong : Phys. Rev. Lett. 90, 196603 (2003).

14) H. Kim and Y. Hasegawa : Jpn. J. Appl. Phys. 55, 08NA03 (2016).

15) A.B. Preobrajenski, M.L. Ng, A.S. Vinogradov and N. Mårtensson : Phys. Rev. B 78, 073401 (2008).

16) A.L. Vázquez de Parga, F. Calleja, B. Borca, M.C.G. Passeggi Jr., J.J. Hinarejos, F. Guinea and R. Miranda : Phys. Rev. Lett. 100, 056807 (2008).

17) B. Wang, M. Caffio, C. Bromley, H. Früchtl and R. Schaub : ACS Nano 4, 5773 (2010).

18) J.M.D. Coey and P.A.I. Smith : J. Magn. Magn. Mater.
200, 405 (1999).

19) C.M. Fang, M.A. van Huis, J. Jansen and H.W. Zandbergen : Phys. Rev. B 84, 094102 (2011).

20) X. Liu, B. Lu, T. Iimori, K. Nakatsuji and F. Komori : Phys. Rev. Lett. 98, 066103 (2007).

21) K. Ienaga, T. Miyamachi, Y. Takahashi, N. Kawamura and F. Komori : Phys. Rev. B 96, 085439 (2017).

22) V. Higgs, P. Hollins, M.E. Pemble and J. Pritchard : J. Electron Spectrosc. Relat. Phenom. 39, 137 (1986).

23) S.M. Driver and D.P. Woodruff : Surf. Sci. 442, 1 (1999).

24) T. Hattori, T. Iimori, T. Miyamachi and F. Komori : Phys. Rev. Mater. 2, 044003 (2018).

25) T. Wiell, J.E. Klepeis, P. Bennich, O. Björneholm, N. Wassdahl and A. Nilsson : Phys. Rev. B 58, 1655 (1998).

26) H.A. Wriedt, N.A. Gokcen and R.H. Nafziger : Bull. Alloy Phase Diagrams 8, 355 (1987).

27) K. Nakajima, S. Okamoto and T. Okada : J. Appl. Phys. 65, 4357 (1989).

28) N. Ji, L.F. Allard, E. Lara-Curzio and J.-P. Wang : Appl. Phys. Lett. 98, 092506 (2011).

29) J.Q. Xiao and C.L. Chien : Appl. Phys. Lett. 64, 384 (1994).

30) J.M. Gallego, S.Y. Grachev, D.M. Borsa, D.O. Boerma, D. Écija and R. Miranda : Phys. Rev. B 70, 115417 (2004).

31) J.M. Gallego, D.O. Boerma, R. Miranda and F. Ynduráin : Phys. Rev. Lett. 95, 136102 (2005).

32) Y. Takagi, K. Isami, I. Yamamoto, T. Nakagawa and $T$. Yokoyama: Phys. Rev. B 81, 035422 (2010).

33) Y. Takahashi, T. Miyamachi, K. Ienaga, N. Kawamura, A. Ernst and F. Komori : Phys. Rev. Lett. 116, 056802 (2016).

34) Y. Takahashi, T. Miyamachi, S. Nakashima, N. Kawamura, Y. Takagi, M. Uozumi, V.N. Antonov, T. Yokoyama, A. Ernst and F. Komori : Phys. Rev. B 95, 224417 (2017).

35) K. Ito, N. Rougemaille, S. Pizzini, S. Honda, N. Ota, T. Suemasu and O. Fruchart: J. Appl. Phys. 121, 243904 (2017).

36) H. Nakagawa, S. Nasu, H. Fujii, M. Takahashi and F. Kanamaru : Hyperfine Interact. 69, 455 (1992).

37) W. Lin, J. Pak, D.C. Ingram and A.R. Smith : J. Alloys Compd. 463, 257 (2008).

38) C. Navio, J. Alvarez, M.J. Capitan, F. Yndurain and R. Miranda : Phys. Rev. B 78, 155417 (2008).

39) M. Sifkovits, H. Smolinski, S. Hellwig and W. Weber : J. Magn. Magn. Mater. 204, 191 (1999).

40) C.D. Ruggiero, T. Choi and J.A. Gupta : Appl. Phys. Lett. 91, 253106 (2007).

41) J.C. Oberg, M.R. Calvo, F. Delgado, M. Moro-Lagares, D. Serrate, D. Jacob, J. Fernández-Rossier and C.F. Hirjibehedin : Nat. Nanotechnol. 9, 64 (2014). 